\title{
The Quaternary alluvial systems tract of the Pantanal Basin, Brazil
}

\author{
Trato de sistemas aluviais do Quaternário da Bacia do Pantanal
Mario Luis Assine ${ }^{1 *}$, Eder Renato Merino ${ }^{1}$, Fabiano do Nascimento Pupim², Hudson de Azevedo Macedo ${ }^{1}$, Mauricio Guerreiro Martinho dos Santos ${ }^{1}$

\begin{abstract}
The Pantanal Basin is an active sedimentary basin in central-west Brazil that consists of a complex alluvial systems tract characterized by the interaction between different river systems developed in one of the largest wetlands in the world. The Paraguay River is the trunk river system that drains the water and part of the sediment load received from areas outside of the basin. Depositional styles vary considerably along the river profiles throughout the basin, with the development of entrenched meandering belts, anastomosing reaches, and floodplain ponds. Paleodrainage patterns are preserved on the surface of abandoned lobes of fluvial fans, which also exhibit many degradational channels. Here, we propose a novel classification scheme according to which the geomorphology, hydrological regime and sedimentary dynamics of these fluvial systems are determined by the geology and geomorphology of the source areas. In this way, the following systems are recognized and described: (I) the Paraguay trunk-river plains; (II) fluvial fans sourced by the tablelands catchment area; (III) fluvial fans sourced by lowlands; and (IV) fluvial interfans. We highlight the importance of considering the influences of source areas when interpreting contrasting styles of fluvial architectures in the rock record.
\end{abstract}

KEYWORDS: Pantanal; wetlands; fluvial megafan; modern depositional environments; alluvial systems tract.
RESUMO: A Bacia do Pantanal é uma bacia sedimentar situada no Centro-Oeste do Brasil, caracterizada pela presença de um moderno trato deposicional aluvial e pela interação de vários tipos de sistemas desenvolvidos em uma das maiores e mais importantes áreas úmidas do planeta. O Rio Paraguai representa o rio-tronco do sistema e drena a água e parte da carga sedimentar recebida de outras áreas extrabacinais. Os rios nos diferentes sistemas apresentam mudanças de estilo fluvial em consequência de fatores alogênicos e autogênicos, com desenvolvimento de cinturōes de meandros incisos, domínios distributários não confinados e mundanças de canal único para padröes multicanal (anabranching). A superficie de lobos abandonados apresenta complexa rede de paleocanais e canais degradacionais tributários superimpostos. Com base na geomorfologia, na hidrossedimentologia e nos processos de sedimentação, é proposta classificação dos sistemas aluviais do trato deposicional do Pantanal em quatro grupos principais: (I) planícies do rio tronco; (II) leques fluviais com bacias de captação em planaltos sedimentares; (III) leques fluviais formados por rios provenientes de terrenos pré-cambrianos arrasados; e (IV) planícies interleques. Os sistemas deposicionais que compóem o trato deposicional do Pantanal, cujos estilos são condicionados por fatores autogênicos (construção e abandono de lobos) e alogênicos (mudanças climáticas e condicionantes tectônicos), são importantes análogos modernos para a interpretaçāo de unidades geológicas de origem aluvial de diferentes periodos do tempo geológico.

PALAVRAS-CHAVE: Pantanal; terras úmidas; megaleque fluvial; ambientes modernos de sedimentação; trato de sistemas aluviais.

\footnotetext{
Instituto de Geociências e Ciências Exatas - IGCE, Universidade Estadual Paulista “Júlio de Mesquita Filho” - UNESP, Rio Claro (SP), Brazil. E-mail: assine@rc.unesp.br ermerino82@yahoo.com.br,hud_azevedo@hotmail.comemauricioguerreiro@yahoo.com

${ }^{2}$ Instituto de Geociências, Universidade de São Paulo - USP, São Paulo (SP), Brazil.E-mail:fabianopupim@gmail.com

*Corresponding author.

Manuscript ID: 20150014. Received: 07/02/2015. Approved: 08/21/2015.
} 


\section{INTRODUCTION}

The Pantanal is an active sedimentary basin characterized by basin-margin faults and multiple subsurface faulted blocks, encompassing a series of depressions in which a more than 500 m-thick sedimentary succession has accumulated (Assine 2003, Assine \& Soares 2004; Fig. 1). Active tectonics is confirmed by recent earthquakes, tectonicallycontrolled streams, and differential subsidence within the basin (Assumpção et al. 2004; Assumpção \& Sacek 2013). The modern depositional system forms the largest tropical wetland in the world (Por 1995), comprising an approximately $150,000 \mathrm{~km}^{2}$ seasonally-flooded area developed most prominently in central-west Brazil (Assine 2015). The various morphologies of the modern depositional systems were previously classified according to landscape features, flooding dynamics and hydroperiods, flowing rivers, vegetation type, and local names (e.g. Hamilton et al. 1996, Silva \& Abdon 1998, Padovani 2010).

The sedimentary successions of the Pantanal Basin record the deposition on a large alluvial plain characterized by the interplay between fluvial fans and megafans, as well as fluvial interfans and a trunk fluvial plain. These distinct alluvial systems are part of a huge depositional tract, which reflects the geomorphological heterogeneity of the basin. The term system tract is used to describe contemporaneous genetically three-dimensional depositional systems (Brown \& Fisher 1977). Here, we propose a novel classification of the alluvial systems of the Pantanal Basin, and organize them into groups of fluvial-system tracts characterized by contrasting catchment areas, namely the Palaeozoic Paraná Basin tablelands, the lowlands of nearby Precambrian metamorphic terrains, and the alluvial plain itself. Particular fluvial styles, sediment load, discharge, and hydrologic regime typifies each system. Many of these rivers change in style downstream, passing from fluvial fans to interfans or, in the case of the Paraguay River, to a trunk river system; aggradation and degradation dominate different parts of individual systems. We characterize the particular hydro-sedimentological functioning of each system and the associated mass transfer to the basin. This study aims at providing a robust classification scheme to understand fluvial systems developed in an actively subsiding tropical basin. The Pantanal Basin is an ideal and exceptional analogue for the development of facies models regarding the interpretation of alluvial successions in the rock record. Implications include the development of a complex and broadly-applicable depositional model for continental

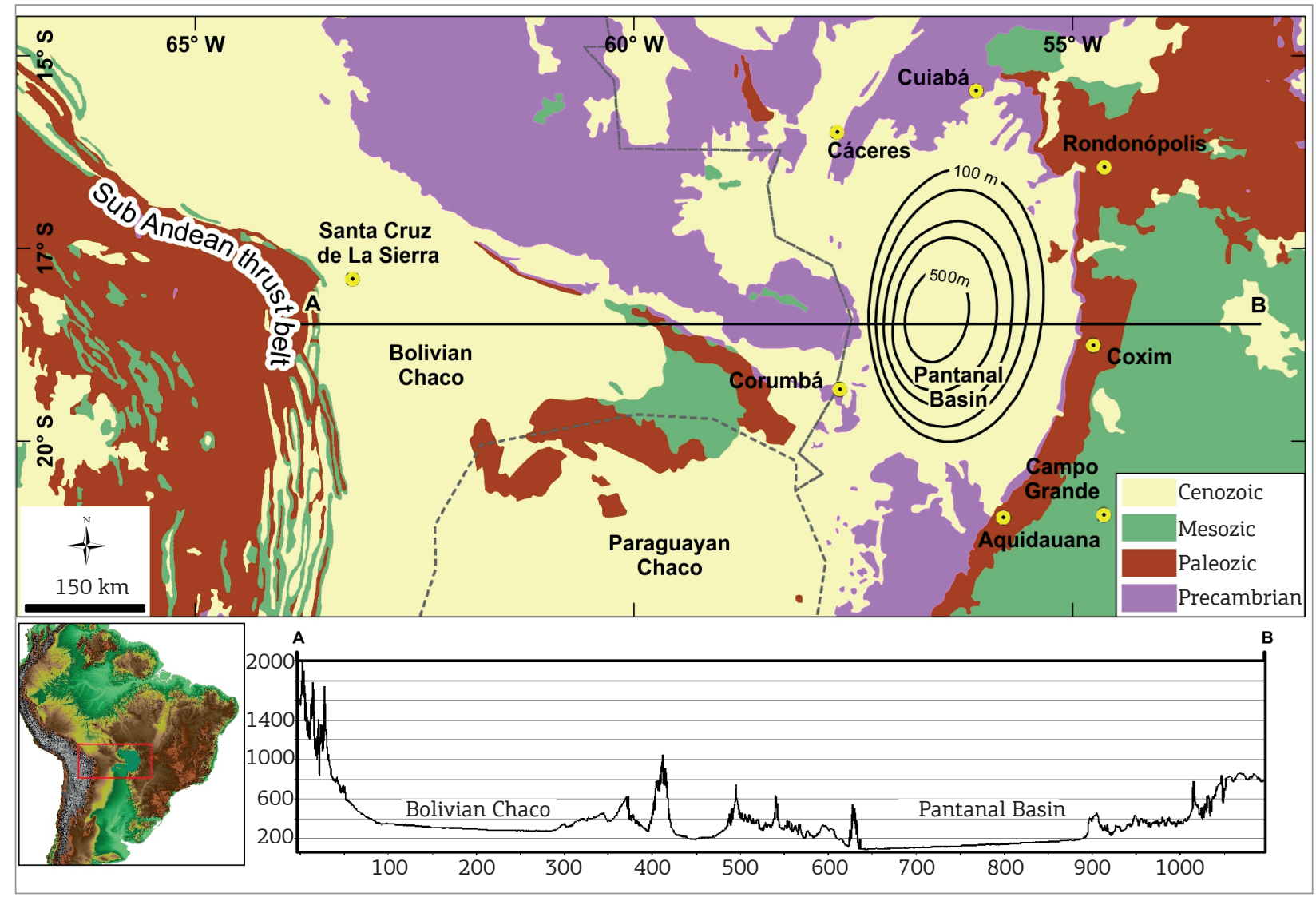

Figure 1. Geological setting of the Pantanal Basin (topographical profile based on South America SRTM-DEM; sediment thickness contours in meters). 
sedimentation in order to predict the overall architecture and facies assemblages of fluvial deposits in the rock record from basin- to outcrop-scale.

The depositional tract of the Pantanal was mapped using several types of orbital data (e.g. Landsat series, GeoCover Circa 1990 and 2000, SPOT, ASTER and MODIS/Terra MOD13Q1; 90 m SRTM digital elevation model - DEM; aerial-photography; geological and geomorphological maps of the Geological Survey of Brazil). High- to medium-resolution spatial, radiometric and multitemporal satellite images were utilized to assess morphological zones and features within the basin. In order to understand the seasonal flood dynamics of the Pantanal and its distinct morphological features under such contrasting water regimes, we used images from both dry and wet season of different years. Hydro-sedimentologic information was obtained from datasets of the Brazilian Water Agency (ANA) (http:// hidroweb.ana.gov.br).

The depositional systems of the Pantanal basin were distinguished based on the following criteria:

- delimitation of the Pantanal plain based on the proposal of Padovani (2010);

- zonation of distinct depositional systems based on morphological similarity recognized on orbital data; mapping of both recent and ancient minor-scale landforms of depositional and erosive nature; and

- identification of paleochannels and other evidence of changes in the river pattern and location through time.

\section{PHYSICAL SETTINGS}

The concentric isopach curves depicted on the Fig. 1 are speculative as they are based on very few subsurface data and overlook the presence of faults. The Pantanal Basin is delimited by active, major brittle faults to the east and west, the dips of which characterized by hundreds of meters of displacement. Differential movement along fault planes can be inferred from the shallow earthquakes commonly registered in the area, and are understood as accommodation-space controls, which likely resulted in the observed large seasonably floodable areas (Fig. 2). Straight limits of flooded areas are indicative of active faulting, however trace faults within the wetland were not mapped yet, and the geological lineaments presented on Fig. 2 indicate the general trends of brittle structures. The basin axis is oriented in a roughly north-south direction. A series of distinct basement rocks surround the basin. Precambrian metamorphic lowlands
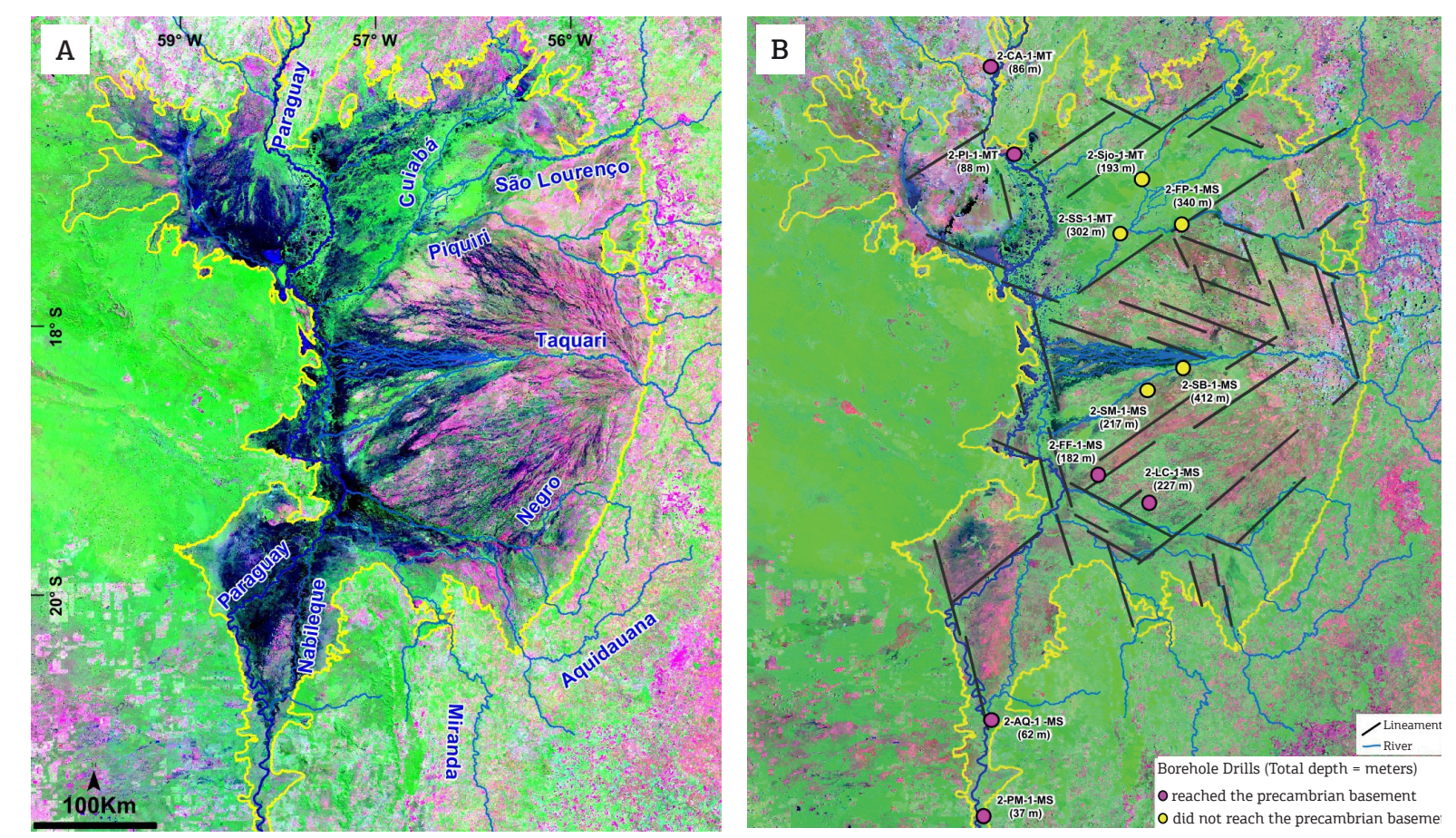

Figure 2. Distinct flooding patterns during dry and wet seasons in the Pantanal wetland (the yellow line is the wetland border). (A) Wet season 2011, MODIS/Terra MOD13Q1 R(MIR)G(EVI)B(Blue) composite band; (B) Dry season of 2008, MODIS/Terra MOD13Q1 R(MIR)G(EVI)B(Blue) composite band. Dark colors in the images indicate flooded areas, which are in many sites tectonically controlled. Geological lineaments indicate the general trends of brittle structures within the basin. 
surround the basin on its north, south and west sides, whereas the tablelands of the Palaeozoic Paraná Basin crop out to the east (Fig. 1).

The eastern margin of the basin is characterized by convex-eastward planform geometry, but the western margin is characterized by a more irregular limit, with many protuberances and segments that are apparently erosional, forming a complex arrangement of fractures of both NNW and WNW strikes. It is likely that many of these fractures were inherited from the underlying basement rocks. The northern limits of the basin are characterized by multifaceted array of NE- and NW- trending fractures, clearly inherited from the basement rocks. The southern limit is marked by the NW-striking Bodoquena plateau, a horst that separates the Pantanal Basin to the northeast and the Chaco Basin to the southwest.

Bedrock rivers draining Paleozoic sedimentary plateaus and dissected Precambrian basement feed the basin. These rivers become unconfined upon entering the basin, where they experience lower gradients and diminished water flow of the wide alluvial plain (Assine \& Silva 2009). The morphological characteristics and the high sediment supply determine the avulsive nature of the active channels and paleochannels, typically resulting in the development of various multichannel systems and distributary planforms further downstream (Assine 2005, Assine et al. 2014). The dominant depositional form is that of a radial, distributive channel pattern (Nichols \& Fisher 2007, Hartley et al. 2010), including megafans, fluvial fans, and small debrisflow-dominated alluvial fans associated with the basin boarder escarpments. This depositional-setting type has been recently suggested as the dominating alluvial style in the alluvial rock record (Weissmann et al. 2010).

The Pantanal Basin preserves up to 500 m-thick deposits that record Quaternary climatic fluctuations, including the Pleistocene highly seasonal rainfall and dry climate, and the Holocene wet and warm conditions (Ab'Sáber 1988, McGlue et al. 2012). Many paleochannel planform observed through satellite imagery on the surface of inactive parts of the modern systems were originated from river-system deposition with styles that markedly contrast with the modern channel systems (Assine \& Soares 2004, Assine et al. 2014, Macedo et al. 2014), providing a clear perspective to understand the climatic and tectonic impacts on fluvial dynamics.

The basin formation has long been associated with the Andean tectonics (Almeida 1959), more specifically to a subsidence model due to extensional stress at the forebulge (Shiraiwa 1994, Ussami et al. 1999) or in the back-bulge domain (Horton \& DeCelles 1997) of the Andes foreland system, which includes the Chaco Basin as the foredeep area. However, the mechanism of basin formation remains unsolved, and new information must be considered, such as the negative velocity anomalies of seismic wave propagation at different lithosphere depths below the Pantanal region (Feng et al. 2007). Besides, the basin initiation during the Quaternary is uncertain and the lack of geochronological data leaves open the possibility that the basin formed much earlier, perhaps during an interval of widespread tectonism in southern Brazil during the Eocene-Miocene (Assine et al. 2015a). Nonetheless, the relict landscapes and the Quaternary surface deposits document the numerous climatic fluctuations of the Cenozoic, providing valuable insights on the overall preserved architecture and facies assemblages that accumulated under such climatic conditions.

The Pantanal is one of the largest wetlands in the world (Por 1995, Fraser \& Keddy 2005, Junk et al. 2006), and most of its landscapes are pristine and home to a rich biodiversity (Alho 2008, Assine 2015). Its savanna climate (Alho 2005) is characterized by mean temperature range between 20 and $27^{\circ} \mathrm{C}$, a negative water balance determined by a precipitation range between 800 and $1,300 \mathrm{~mm}$, and evaporation range between 1,300 and 1,600 $\mathrm{mm}$. The wetland environment is guaranteed by water inflow from the surrounding plateaus, and facilitated by slow surface runoff (promoted by low river-plain gradients), and infiltration and retention by the sandy alluvial plain (Assine et al. 2015b). The presence of standing water is critical for both patterns of biodiversity and biogeochemical cycling.

\section{DEPOSITIONAL TRACT}

The Pantanal sedimentary basin comprises a complex depositional tract composed of various fluvial systems, located within the Upper Paraguay River drainage basin. This large-scale alluvial plain consists of a dynamic system of floodplains and fluvial fans with heterogeneous river channels network connected to the axial Paraguay River. The Paraguay River flows from north to south, and is characterized by intricate morphology of contrasting river plain styles from its entrance into the basin and throughout the alluvial plain until the southernmost area of the Pantanal, through the Bodoquena Plateau, where it enters the Chaco Basin. The Taquari, São Lourenço and Cuiabá rivers, the main tributaries of the Paraguay, form major megafan systems characterized by flow vectors mainly oriented in a transverse direction to the basin axis. There are also a number of smaller-scale, but not less important, river systems, such as the Itiquira, Negro, Taboco, Aquidauana, Jaurú, Miranda, Nabileque, and Corixo Grande rivers. Some of these rivers develop particular and varied channel patterns characterized by multichannel distributary planforms with progressive 
decreasing of river-channel widths and discharge; other rivers form large-area permanently floodbasins and complexly-developed lacustrine systems.

The Pantanal is an exorheic basin (i.e., externally drained), with the Paraguay River carrying water and sediment to the Chaco Basin. However, most of the sediment loaded by rivers is deposited within the Pantanal wetland. Data from gauge stations of the main rivers (Paraguay, Cuiabá, São Lourenço, Piquiri, Taquari, Aquidauana, and Miranda) at their entrance into the Pantanal reveal that the suspended sediment supply to the basin is -25 million ton/year. Only $10 \%$ of this total is recorded in fluvial stations located in the Paraguay River south of the Nabileque fluvial fan (Porto Murtinho gauge station), which means that $90 \%$ of the sediment-load is retained in the Pantanal basin. The presence of many bars indicates very high bottom traction transport in most of the Pantanal rivers, but there is no information about the amount of bed-load sediment supply to the basin.

A classification scheme describing the Pantanal basin, in which distinct systems are related to specific source-area geomorphologies (Fig. 3), is here proposed. We identify four primary categories:

the Paraguay trunk-river plains;

- fluvial fans sourced by the tablelands catchment area;

- fluvial fans sourced by lowlands; and

- fluvial interfans.

Debris-flow-related alluvial fans occur on the basin-boarder pediment slopes associated with the eastern tableland escarpments, characterized by coarse-grained sandstone and matrix-supported conglomerate; and calcretes and ferricretes duricrusts associated with some of these deposits (Boggiani \& Coimbra 1995, Nascimento et al. 2015). Smaller-scale alluvial plains are mapped in the basin-border, but will not be discussed in this paper. Other features include complex floodplain-lake systems, which are characterized by various forms and scales, and contrasting chemical properties (McGlue et al. 2011, McGlue et al. 2015). Such lakes are developed in areas of active floodplains, as well as in abandoned parts of megafans. Some were formed by water damming resulting from meander-belt aggradation and basin-boarder confinement, whereas others present orientations which can be related to tectonic controls and other mechanisms not clearly understood yet, including long-term climatic fluctuations (Bezerra \& Mozeto 2008; McGlue et al. 2012).

\section{Tableland-catchment fluvial fans}

Tableland-catchment fluvial fans are located in the eastern limits of the basin and are sourced by dissected sedimentary tablelands developed on Paleozoic-Mesozoic deposits of the Paraná sedimentary basin. Deep fluvial erosion in the catchment area is responsible for high sediment yield carried to the Pantanal Basin. The sediment yield of these fluvial systems can reach 22.5 million ton/year, being responsible for $-90 \%$ of total suspended load sediment supplied to the Pantanal Basin. The suspended sediment loaded by the Taquari River is nowadays the largest, reaching up to $72 \%$ of the total.

Crossing sharp escarpments and leaving the catchment area within the plateau, these rivers form large-scale fluvial fans (megafans) by depositing their sediment loads as a result of much reduced topographic gradients within the Pantanal Basin. Famous examples of such fans are the Taquari and São Lourenço megafans (Figs. 3 and 4), large-scale systems characterized by modern distal depositional lobes and feeder rivers entrenched in upper fan Pleistocene-aged alluvial deposits. The Aquidauana, Taboco, Itiquira and Negro megafans belongs to this group, but are characterized by smaller areas (Fig. 3).

The Taquari River forms the largest megafan of the Pantanal Basin, with an area of $-50,000 \mathrm{~km}^{2}$, accounting for about 37\% of the Pantanal Basin area (Assine 2003, Zani et al. 2012). The river is characterized in its alluvial reaches by an entrenched meander belt in the upper fan (Figs. $4 \mathrm{~A}$ and 5A), but loss of confinement downstream of the intersection point results in multiple, narrow and shallow distributary channels, progressively decreasing in discharge and forming the modern lower-fan lobe (Assine 2005). This megafan is easily visible in satellite imagery and accumulates large volume of sediments, particularly on its floodbasin (approximately 16 million ton/year). Avulsion is the main process within this system that typically develops by progradation of splays into floodbasin accommodation, with many events recorded on large-scale geomorphic features, such as avulsion belts and diverted paleochannels (Assine 2005, Buehler et al. 2011). The southern part of the Taquari megafan is marked by more than 10,000 shallow lakes, in a region named Nhecolândia. Those circular to elliptical small lakes are elongated in a NE direction, and their margins are bordered by up to $5 \mathrm{~m}$-height sand ridges. Most of them are seasonally flooded, and present freshwater hydrochemistry and intense colonization by aquatic macrophytes. Some of these lakes $(-10 \%)$ are isolated from pluvial surface flow and are characterized by white-sand beaches and brackish to saline water, with large proliferation of cyanobacteria. These lakes are alkaline salines and present $\mathrm{pH}$ values of up to 10 , with the presence of bicarbonate, chlorinated and sodic waters (Barbiéro et al. 2002).

The São Lourenço megafan is the third largest megafan of the Pantanal, with an approximate area of 13,000 $\mathrm{km}^{2}$. It records the succession of multiple fluvial-channel styles developed since the Pleistocene. Ancient fan lobes preserve 
numerous paleochannels, which exhibit various planform styles that typically diverge downstream into minor distributary channels; the styles evolved from the ancient multi-thread braided channels to modern sinuous channels (Corradini \& Assine 2012). Such channel-style evolution occurred as the result of climatic fluctuations, from Late
Pleistocene dry conditions leading to braided-channel deposition, to Holocene warmer and wetter climatic settings leading to meandering-channel deposition (Assine et al. 2014). This evolution of fluvial-channel styles is reflected in an overall finning-upward trend, ranging from the basal coarse-grained sands (related to the older braided-channel

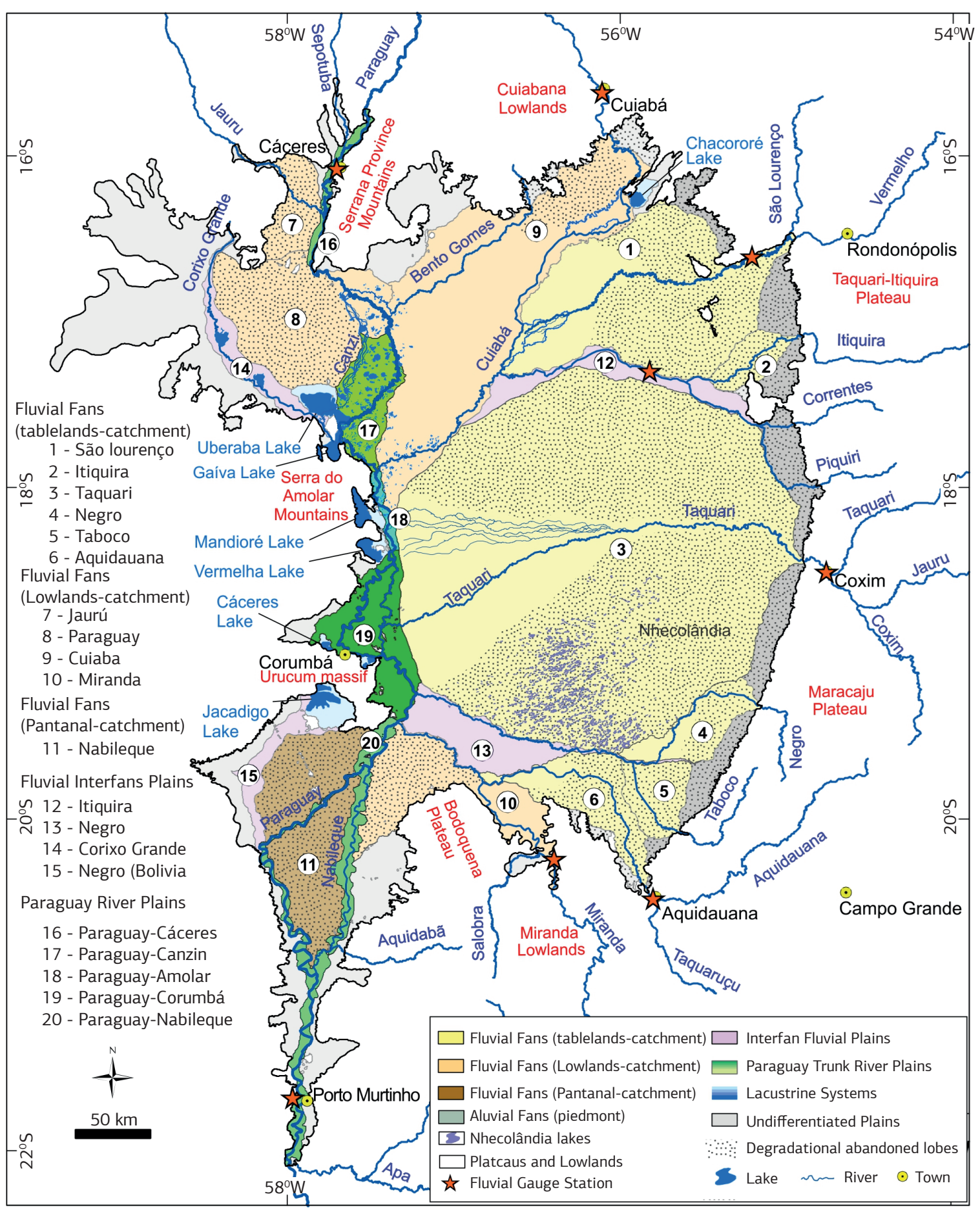

Figure 3. Depositional systems tract. 
deposition) to fine-grained sand, siltstone and clay of the younger deposits. The distal reaches of the São Lourenço megafan are characterized by depositional lobes of distributary channel-levee ridges, which resulted from progradation onto an unconfined floodbasin (Assine et al. 2014; Fig. 4B). Approximately 1.3 million ton/year of suspended sediment is deposited on both distal (present lobe) and middle reaches of São Lourenço megafan.

The Aquidauana megafan is located in the SE region of the Pantanal Basin and presents a flow direction to the NNW. It flows through an incised meander belt on its proximal reaches, passing downstream into a wide river plain on its distal reaches where channel-levee complexes are located on higher altitudes than its surrounding floodplains, with many recorded crevasse-splays and frequently flooded floodplains (Facincani \& Assine 2010). Similarly, the Negro River fan presents an entrenched belt on its abandoned Pleistocene lobe and an unconfined plain with low gradient anabranching channels on its distal portion (Cordeiro et al. 2010, Mendes 2014). The Itiquira and Taboco megafans technically belong to this group of systems, but now they are dominated by degradational processes associated with sheet-flow
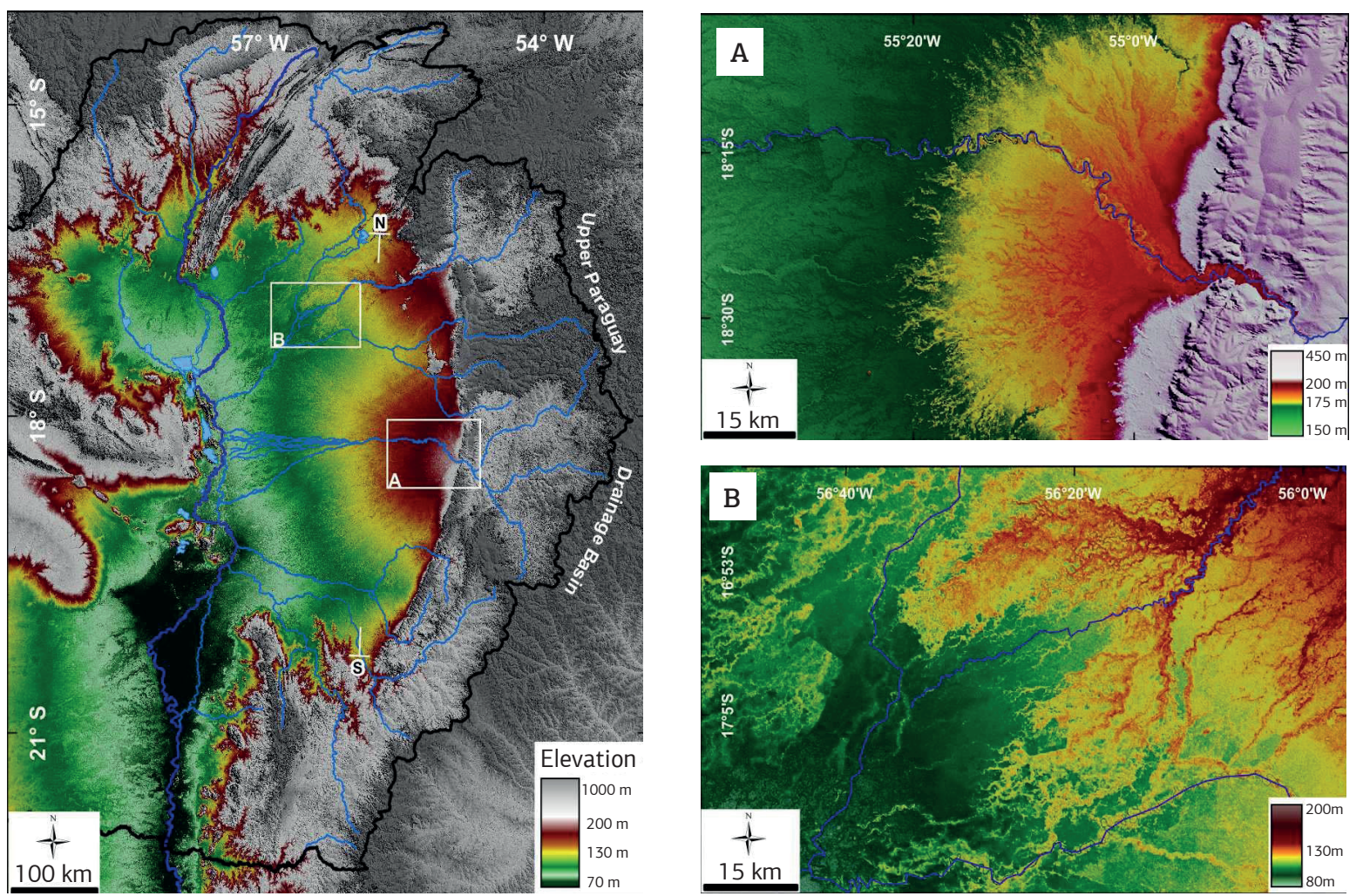

C

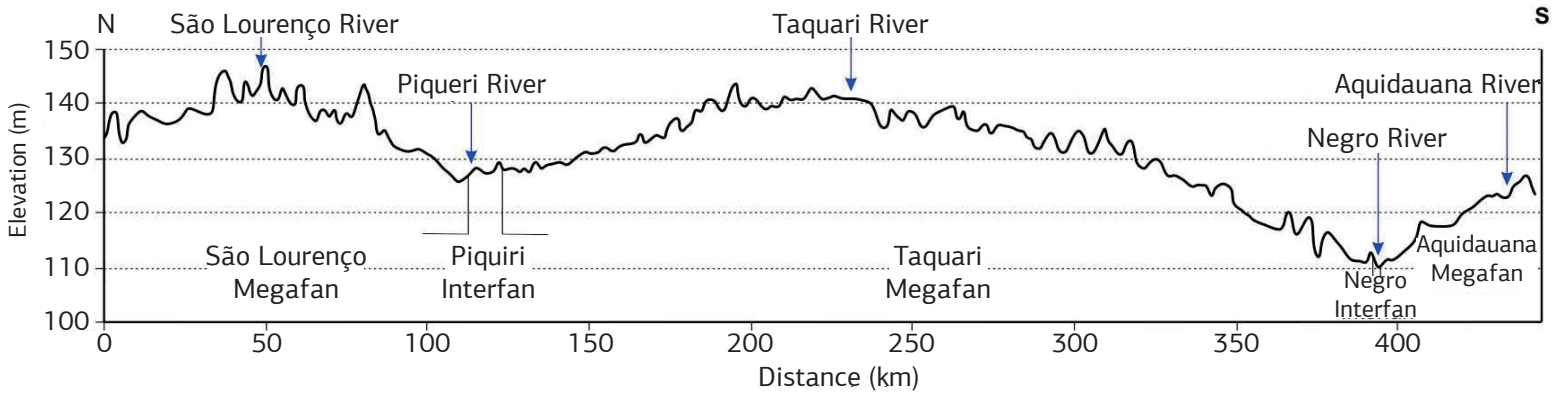

Figure 4. Digital elevation model (90m SRTM-DEM) of the Upper Paraguay drainage basin showing the Pantanal wetland, the alluvial rivers and their sediment-source catchment areas. (A) The Taquari meander belt, confined within an incised valley in the upper megafan setting. (B) Distributary channels and paleochannels in the modern depositional lobe of the São Lourenço megafan.(C) Topographic contrast among rivers in megafan and interfan systems. 
during the annual flooding season, and no longer function as effective depositional fluvial fans.

\section{Lowland-catchment fluvial fans}

Lowlands-catchment fluvial fans are sourced by sediments from the surrounding Precambrian igneous and metamorphic rocks. The sediment yield of these systems is much smaller when compared with the tableland-catchment fluvial fans, once they have less than 1.1 million ton/year of suspended load.

The Cuiabá fluvial-fan system is the second largest megafan of the Pantanal Basin and the major megafan of this category of system tract. It comprises a $15,000 \mathrm{~km}^{2}$ area in the northern part of the Pantanal Basin, presenting an elongate and broad active depositional lobe characterized by a main channel, which presents numerous crevasse splays and a floodplain area characterized by many abandoned channels and fine sandy lobes. Its Pleistocene lobe is relatively small when compared with abandoned lobes of other systems, but it clearly shows ancient braided bifurcating channels. The active channel belt is characterized by low gradients $(-0.20 \mathrm{~m} / \mathrm{km})$, and is entrenched in the proximal parts of the fan. Drainage patterns considerably vary along the river path through the basin and are characterized by both meandering and anabranching channel planforms (Pupim 2014).

The Paraguay River flows in a meander belt entrenched in Pleistocene deposits in the northwest border of the Pantanal wetland (Fig. 5B). Downstream, the river forms a fluvial megafan because of a loss of valley confinement and decreasing topographic gradient when it enters the Pantanal Basin. Paleochannels are preserved on the surface of a Pleistocene-aged abandoned fan lobe, forming cross-paleodrainage networks. A main meandering channel, which is the Paraguay River proper, dominates the active depositional lobe, with bifurcations that forms anabranching channels, as well as hundreds of small lakes. The topographic gradient abruptly diminishes at the base of the modern depositional lobe and the Paraguay fluvial plain style changes downstream from this point (Assine \& Silva 2009).

The Miranda River fluvial fan exhibits a different morphologic fluvial style, displayed by a mostly meandering channel in its fluvial plain reaches, with an alluvial ridge characteristically occupying higher elevations than the surrounding floodplains that progressively widens downstream. Aggradational domains
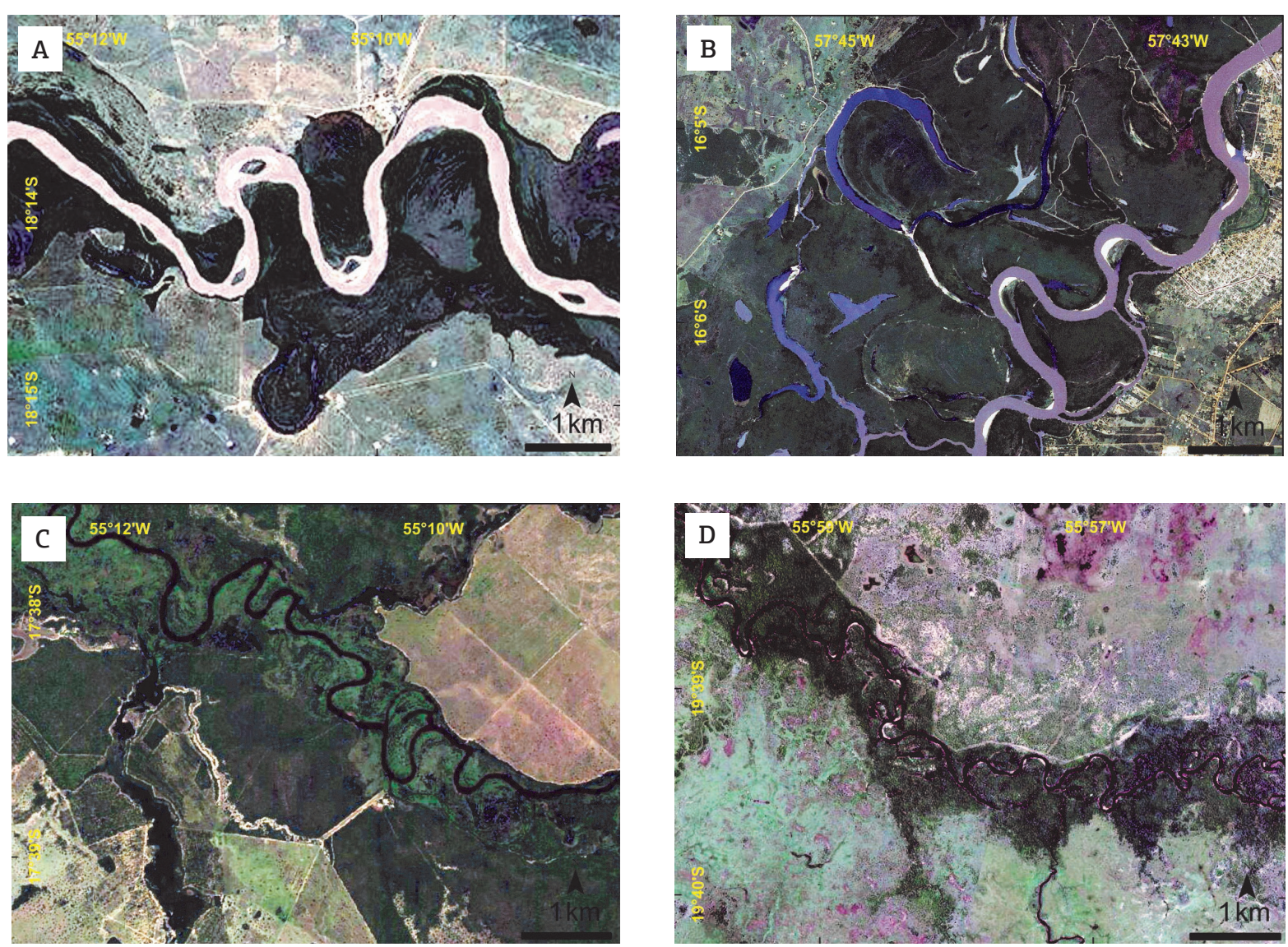

Figure 5. Meander Belts. (A) Taquari River; (B) Paraguay River; (C) Piquiri River; (D) Negro River. All images acquired from the online Basemap ArcGIS 10.2.2. 
of this system are located on the proximal portion of the fan, and this markedly contrasts with most of the other fluvial systems of the basin. Along its lower course, the river flows in a meander belt incised over Pleistocene alluvial deposits, with many preserved oxbow lakes. The river is mostly degradational on its distal reaches, incising paleochannel belts with varied channel widths and morphologies. Pluvial sheet flows commonly erode the surrounding fluvial plain, which are also drained by small ancient distributary channels during major floods (Merino et al. 2013).

\section{Interfan riverplains}

Interfan systems are fluvial plains placed in between fluvial fans (Sinha \& Friend 1994). This kind of system presents increasing fluvial discharge and sediment load downstream. The Corixo Grande river plain is located in the northwestern border of the Pantanal wetland, and collects water and sediment derived from abandoned lobes of the Paraguay megafan, forming undifferentiated alluvial plains created by ephemeral streams originated from the Bolivian territory. The Negro River plain (Bolivia/Paraguay) is another interfan system that contours the fringe from the Nabileque megafan and also drains waters from the Otuquis-Tucavaca and Pilcomayo megafans, which are situated to the west (Kuerten \& Assine 2011). Sediment-source analyses indicate that the sediments of these systems are derived from reworking of previously deposited sediments on the alluvial tract, implying that these are plains-fed systems. The semi-arid climate westward to the Brazilian Pantanal determines the intermittency of such rivers.

The Piquiri and the Negro interfan river plains separate the Taquari megafan from coalescent megafans at its north and south borders (Fig. 3). Both rivers are perennial and flow in meander belts confined within incised valleys (Fig. 5C and 5D). The meandering fluvial style is constant along the entire Piquiri course (Pupim et al. 2014), but the Negro River shows many changes in its fluvial style, crossing a permanently flooded basin downstream, where the river changes to a multichannel-planform pattern (Mendes 2014). Although both river interfan systems receive water and sediment mainly from within the alluvial domain, i.e. from the adjacent fluvial fans, they are also supplied from water and sediments coming from piedmont alluvial fans, and directly from the tablelands-catchment areas. These interfan-river plains can be classified as mixed-fed systems, as the sediment supply originates from different source areas.

\section{Paraguay trunk river plains}

The Paraguay River flows from north to south and is the trunk fluvial system of the Pantanal Basin. It is characterized by complex geomorphic features reflecting the tectonic control on the western margin of the Pantanal basin, and interactions with the distal portion of the other fluvial megafans, developing multiple styles from its entrance in the basin to its exit, where it joins the Chaco Basin further south. The river-mainstream plain comprises five distinct fluvial-floodplain compartments, each one presenting distinct depositional forms, channel pattern and hydrologic behavior (Fig. 6).

The Paraguay-Cáceres river-plain reach is located onto a north-northeast-oriented valley incised on Precambrian crystalline rocks; it exhibits a 4-5 km-wide aggradational meander belt, constrained by the Jaurú fluvial fan at the right and the NE- oriented ridges of Província Serrana Mountains at the left margin. The river gradient is relatively steep $(6.30 \mathrm{~cm} / \mathrm{km})$, and the channel has irregular meanders with some small anabranching channels, oxbow lakes and islands along this reach. When the Paraguay River enters into the Pantanal basin, the river gradient decreases $(5.9 \mathrm{~cm} / \mathrm{km})$, and a channel bifurcation forms the modern lobe of the Paraguay megafan. The $30 \mathrm{~km}$-long Taiamá Island resulted from an important bifurcation (Bracinho River, to the left), and the downstream channel rejoining. Recently, crevasses upstream the Taiamá Island are diverting considerable volume of water flow into the floodplain on the right margin of the river, where the Canzi River develops an anabranching-channel system (Assine and Silva, 2009).

The Paraguay-Canzi river plain is characterized by low-gradient $(2.6 \mathrm{~cm} / \mathrm{km})$ floodplain areas with many abandoned meander channels, large-scale seasonal floods, and numerous observed crevasse-splays. Hundreds of lakes form in the floodplain, including the largest, Lake Uberaba, as well as the large Gaíva Lake. This fluvio-lacustrine plain is a large area of active sedimentation, receiving water and sediment from the Paraguay and Canzi rivers, the Cuiabá megafan, basin-margin drainages, and peripheral channels of the Corixo Grande interfan system.

The Paraguay-Amolar river plain is a confined floodplain bordered by the Serra do Amolar mountains and the Cuiabá and Taquari megafans. This setting creates a narrow $(6 \mathrm{~km})$ and long $(53 \mathrm{~km})$ floodplain, constricting the river flow (hydraulic bottleneck) and creating a continuous water body upstream this reach. The Mandioré and Vermelha lakes arose at the right margin of the Paraguay River because of damming by meander-belt aggradation (McGlue et al. 2011). The Paraguay-Corumbá river plain placed downstream of the Vermelha Lake is characterized by a $27 \mathrm{~km}$-wide plain drained by an anabranching reach formed by the Paraguay and the Paraguay-Mirim Rivers. This wide floodplain is abruptly closed at the mouth of the Miranda River, establishing an additional bottleneck to the Paraguay River flow (Assine et al. 2015b). This flat floodplain (gradients around $2.0-2.3 \mathrm{~cm} / \mathrm{km}$ ) is not homogeneous, but covered by paleochannels of anabranching channels of the ancient Paraguay River (Macedo et al. 
2014). Inactive during the low-medium water level, these paleochannels receive water during the floods.

In the southernmost limit of the basin, the Paraguay River enters in the less subsiding area, where it crosses the Nabileque megafan in a narrow meander belt incised into Pleistocene-aged deposits (Kuerten \& Assine 2011). Sponge spicules analysis in the Nabileque megafan indicate that this fan is a relict feature that was constructed by the Paraguay River during the Pleistocene (Kuerten \& Assine 2011, Kuerten et al. 2013). Most of the Nabileque megafan surface is subject to degradation, but abandoned lobes can be recognized by the existence of an intricate network of distributary paleochannels on its surface.

\section{SYSTEMS TRACT SEDIMENTARY DYNAMICS}

The complex flood regime of the Pantanal Basin and the varied nature of the source rocks from which sediments are provided to the basin determine the heterogeneity of this large-scale alluvial plain, and the geology of source areas plays a fundamental role in the development of the fluvial fans, particularly in terms of sediment supply, river gradients, and depositional dynamics. As demonstrated above, each group of system tracts is characterized by common geomorphological features which are partially derived from the processes
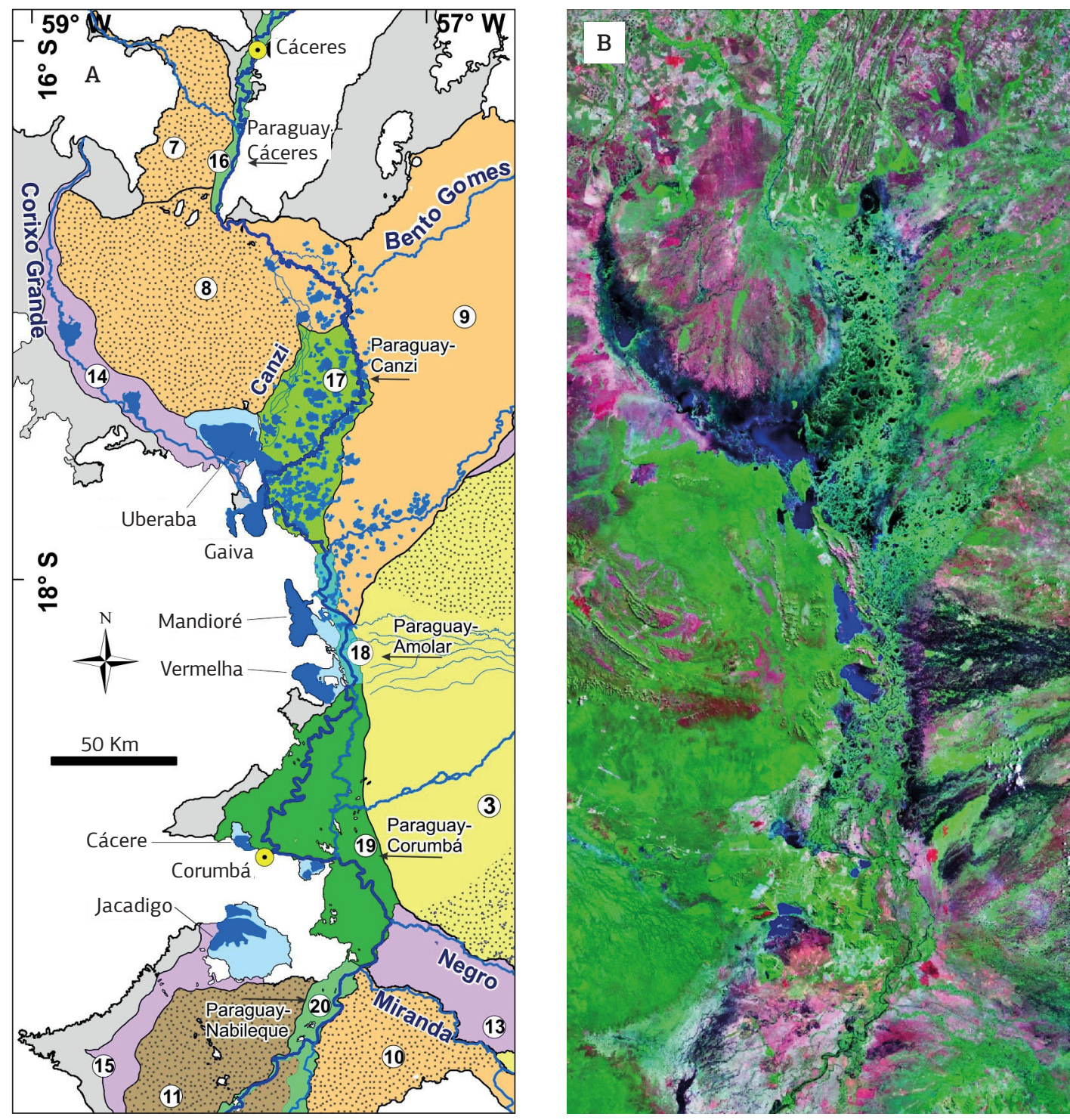

Figure 6. The Paraguay trunk river system is located on the western border of the Pantanal basin (A) Depositional systems that compose the Paraguay river plains (legend captions in the Fig. 3); (B) Landsat satellite image composition GeoCover Circa 2000. 
involved in the sediment and water transfer from the plateau to depositional lobes. The largest catchment areas are commonly translated into larger modern fluvial fan areas, with the Taquari as the most prominent example (Figs. 3 and 4).

Sediment is readily available in finer-grained particles for fluvial transport in tableland-catchment fluvial fans because the source rivers drain Paleozoic and Mesozoic recycled siliciclastic rocks of the Paraná Basin. These rivers are deeply incised into their bedrocks in the catchment area, as opposed to rivers draining lowland areas, which results in higher fluvial plain gradients. This situation results in elevated proportions of sediment load, and partly determines the nature and the governing dynamics of the related fluvial fans, particularly the Sáo Lourenço and Taquari megafans. These fans notably constitute the most active depositional sites of the basin. Entrenched meander belts at their upper portions and overall sediment bypass presently characterize these megafans. Such belts are apparently related to a past regional incision event that proceeded major changes in depositional dynamics, which resulted in a transition from Pleistocene-aged braided fluvial-channel planforms, observed in the inactive part of the megafans, to the observed meandering and anastomosing forms in the active depositional lobes (Assine 2005, Assine et al. 2014). This event resulted in intense pedogenesis, which is reflected in aerially- and laterally-extensive horizons of preserved paleosols presenting both calcrete and ferricrete (Nascimento et al. 2015).

The catchment area of the lowlands systems drain smaller and degraded areas of igneous and metamorphic source rocks from the Precambrian shield, providing relatively low amounts of sediment, and frequently resulting in sedimentary-load deficits, as observed in the Cuiabá Megafan (Pupim 2014). The interfan systems are also characterized by entrenched meander belts, which are similar in width and form to the meander belts developed in the upper portion of the above described megafans (Fig. 5). The regional base-level is determined by the Paraguay trunk river plains. Although abandoned parts of modern lobes do not receive water-flow from rivers, they do receive from pluvial runoff, especially during the wet season, developing networks of tributary streams and reworking previously deposited sediments. These sediments can be redeposited on interfan plains and potentially further transported by the river and delivered to the trunk river system.

Fluvial-system processes act to compensate multiple environmental variables such as climate, basin settings, and the dynamics of depositional construction. The planform geometries that arise ultimately reflect the interplay of these environmental gradients. Alluvial rivers constantly regulate their depositional equilibrium through changes in channel and slope geometries, developing multiple styles as a response to different sets of variables (Tooth 2000, Nanson \& Huang
2008). These variables are collectively classified as autogenic, i.e. related to the depositional environment (e.g. flow dynamics, sediment type), and allogenic, i.e. related to mechanisms which are external to the depositional dynamics (e.g. climatic fluctuations, tectonic dynamics). However, in natural conditions, the clear distinction between auto- and allogeneic process is not a simple task, because detailed field data are needed to quantify the relative importance of each process and due the complicated interactions among these controls exist (Miall 1996, Bridge 2003, Stouthamer \& Berendsen 2007).

Differential subsidence of distinct blocks of the Pantanal Basin, the rejuvenation of source-areas, base-level and river-profile changes, and the reactivation of basin-boarder faults, are fundamental allogenic variables that need to be addressed in order to understand the particular depositional and flood dynamics of the Pantanal alluvial plains. Climate changes throughout time impact atmospheric precipitation, water availability, biogeography (e.g. vegetation cover), river discharge, and the nature of floods. Modern-day climate in the Pantanal is characterized by strong seasonality, with higher rates of precipitation occurring during the summer (December/March) and long flood periods (February/June).

Autogenic controls in the Pantanal influence the transfer of sedimentary material from the terrains located on areas above base-level to areas which are created by newly-available accommodation space, balancing rates of erosion and sedimentation. Fan and interfan interactions are characterized by aggradation on some areas, while degradation prevails on other areas. Stream flow discharge, pluvial surface runoff, infiltration, water-residence period, types of surface flow, and river channel dynamics cooperatively influence the distinct types of fluvial styles developed in rivers of the Pantanal Basin. Allogenic controls influence the depositional-systems dynamics of the Pantanal alluvial plain, and frequently result in river avulsions, a very well-known phenomenon among the local population. Such avulsions occur after levee disruption and progradation of channel sediments over lowland floodplains, followed by distributary-channel development, and eventual main channel deviation to the newly formed one (Slingerland \& Smith 2004, Assine 2005; Fig. 7). Combined effects of both auto- and allogenic controls can be observed throughout the Paraguay River fluvial plain. For example, the river develops a fluvial megafan at its entrance on the Pantanal Basin due to loss of confinement and, downstream, the river becomes meandering and flows in a vast floodbasin. The conjugation of uplifted basin-boarder fault at Serra do Amolar on the right margin and the progradation of the modern lobe of the Taquari River on the left margin of the Paraguay River constrain the channel and creates river bottleneck, favoring backwater flooding upstream of the Serra do Amolar. 
The auto- and allogenic process have different effects in the Pantanal system-tract sedimentary dynamic. The long-term cycles as the channel pattern changes, and deposition-erosion cycles can be attributed to allogenic factors of which climate appears to have driven the main changes during the late Quaternary. The short-term cycles as avulsions in distal fluvial fans and meandering migration are mainly related to autogenic factors.

\section{CONCLUSION}

The Pantanal is an active sedimentary basin with faults and associated earthquakes reflecting distinct basin blocks subsidence. Accommodation space generation results in discrete groups of fans, megafans, interfans and floodplain systems. The present work shows the first classification according to hydro-sedimentological settings, a classification that allows a comprehensive distinction of the Pantanal alluvial systems, with each group being characterized by particular geomorphologic features, hydrological regimes and sedimentological dynamics. The results presented herein highlight the role played by source areas and drainage surface flow in influencing sedimentation dynamics in fluvial systems. These roles originate a markedly complex heterogeneity that can be easily depicted in the modern alluvial plain of the Pantanal Basin.

- Tablelands-catchment fluvial fans in the eastern limits of the basin sourced by dissected sedimentary tablelands related to the Paraná Basin deposits comprise major examples of megafans with higher sediment load. The Taquari and São Lourenço present key examples of active megafan on the basin. These systems are characterized at
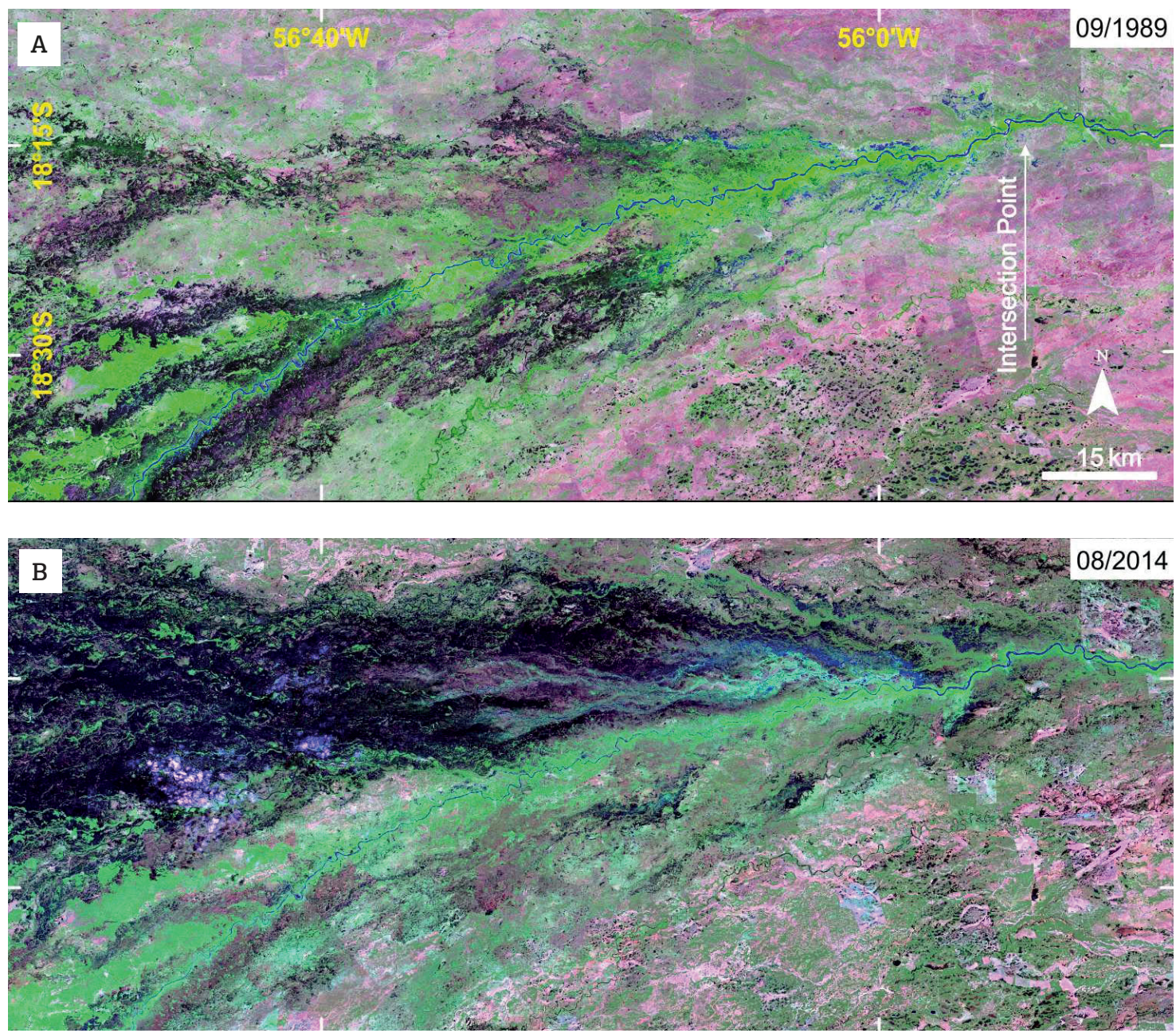

Figure 7. An important avulsion is in progress in the Taquari River at the Caronal farm. (A) There are no important crevasses in September 1989 (Landsat TM5 R7G4B3 composite band); (B) Downstream the intersection point, many crevasses and distributary channels are present on the right margin of the Taquari River in August 2014 (Landsat 8 OLI R7G5B3 composite band). 
their entrance in the Pantanal by confined valleys, which are incised onto Pleistocene-aged deposits, and evolve at the distal portion by progradation of distributary lobes. Minor, and non active, systems are the Aquidauana, Negro, Taboco and Itiquira megafans.

- Lowlands-catchment fluvial fans sourced by sediments from the surrounding Precambrian igneous and metamorphic rocks represent the second category of megafans, with the representative Cuiabá megafan as the second largest within the basin. The sediment load of these megafans is considerably smaller than the tablelands-sourced fans. Other examples of these systems are the Paraguay, Miranda and Jaurú megafans.

- Interfan fluvial systems represent smaller and confined floodplains developed at the fringe of major megafans systems, with different hydro-sedimentological settings characterized by downstream-increasing water discharge and sediment load, as a result of its confinement by the fringe of the megafans. The Itiquira and Negro interfan systems were mainly incised by perennial rivers, whereas the Corixo Grande and Negro (Bolivia) are intermittent and sourced mainly by distributary fan channels.

- The Paraguay trunk-river plains is a complex geomorphic system controlled by the Paraguay River developing multiple styles from its entrance in the basin to its exit, where it joins the Chaco Basin further south. The river-mainstream plain comprises from north to south five distinct fluvial-floodplain compartments, each one presenting distinct depositional forms, channel pattern and hydrologic functioning. The Paraguay and the Nabileque megafans also play important roles on the floodplain affecting the water discharge and the sediment yield, mainly during the annual floods.

Autogenic (e.g. flow dynamics, sediment type) and exogenous variables (e.g. climatic fluctuations, tectonic dynamics) control the evolution of the Pantanal Basin and its depositional systems. The variable nature of the rivers in the Pantanal basin provides evidence for paleohydrological changes that are controlled by avulsion processes, fluvial discharge fluctuations and regional base level variations that have been occurring since the Pleistocene.

The Pantanal Basin provides modern analogues for sedimentation dynamics in sedimentary basins dominated by depositional alluvial systems tract under semiarid to humid climates, and the preserved architecture and facies assemblages of these systems can provide various insights on the prediction of genetically-related deposits in the rock record. The varied depositional tracts determined by different source areas can develop strikingly contrasting lithological geometries and facies assemblages at the same stratigraphic level. This situation can lead to inaccurate interpretations if the influence of source areas on the preserved architecture and sedimentary facies are unaccounted for when studying fluvial successions in the rock record.

\section{ACKNOWLEDGEMENTS}

The authors thank the São Paulo Research Foundation (FAPESP 2014/06889-2; 2014/13937-3; 2014/23334-4) for financial support to our research in the Pantanal Basin; the National Council of Technological and Scientific Development (CNPq) for grants to MLA (308563/2013-1); Michael M. McGlue for critical evaluation and helpful suggestions to improve the text; Aguinaldo Silva for scientific collaboration and logistical support in the field; and the BJG editors Umberto G. Cordani and Claudio Riccomini for the invitation and encouragement to write this work.

\section{REFERENCES}

Ab'Sáber A.N. 1988. O Pantanal Mato-Grossense e a teoria dos refúgios. Revista Brasileira de Geografia, 50:9-57.

Alho C.J.R. 2005. The Pantanal. In: Fraser L.H. \& Keddy P.A. (ed.) The World's Largest Wetlands - Ecology and Conservation. Cambridge University Press, 203-271.

Alho C.J.R. 2008. Biodiversity of the Pantanal: response to seasonal flooding regime and to environmental degradation. Brazilian Journal of Biology, 68:957-966

Almeida F.F.M. 1959. Traços gerais da geomorfologia do CentroOeste brasileiro. In: Almeida FFM Lima M.A. (eds) Planalto CentroOcidental e Pantanal Matogrossense. Guia de Excursão no 1 do XVIII Congresso Internacional de Geografia. Conselho Nacional de Geografia, Rio de Janeiro, p 7-65
Assine M.L. 2003. Sedimentação na Bacia do Pantanal MatoGrossense, Centro-Oeste do Brasil. Tese de Livre-Docência, Universidade Estadual Paulista - UNESP, Rio Claro, 106p.

Assine M.L. 2005. River avulsions on the Taquari megafan, Pantanal wetland, Brazil. Geomorphology, 70:357-371.

Assine M.L. 2015. Brazilian Pantanal: A Large Pristine Tropical Wetland. In: Vieira B.C., Salgado A.A.R., Santos L.J.C. (ed.) Landscapes and Landforms of Brazil. Springer Netherlands, (World Geomorphological Landscapes), 135-146.

Assine M.L., Corradini F.A., Pupim F.N., McGlue M.M. 2014. Channel arrangements and depositional styles in the São Lourenço fluvial megafan, Brazilian Pantanal wetland. Sedimentary Geology, 301:172-184. 
Assine M.L. \& Silva A. 2009. Contrasting fluvial styles of the Paraguay River in the northwestern border of the Pantanal wetland, Brazil. Geomorphology, 113:189-199.

Assine M.L. \& Soares P.C. 2004. Quaternary of the Pantanal, westcentral Brazil. Quaternary International, 114:23-34.

Assine, M.; Merino, E.; Pupim, F.; Warren, L.; Guerreiro, R.; McGlue, M. 2015a. Geology and Geomorphology of the Pantanal Basin. In: I. Bergier and M. L. Assine (eds.), Dynamics of the Pantanal Wetland in South America. Springer Berlin, Heidelberg.

Assine, M.; Macedo, H.; Stevaux, J.; Bergier, I.; Padovani, C.; Silva, A. 2015b. Avulsive Rivers in the Hydrology of the Pantanal Wetland. In: I. Bergier and M. L. Assine (eds.), Dynamics of the Pantanal Wetland in South America. Springer Berlin, Heidelberg.

Assumpção M. \& Sacek V. 2013. Intra-plate seismicity and flexural stresses in central Brazil. Geophysical Research Letters, 40:487-491.

Assumpção M., Schimmel M., Escalante C., Barbosa J.R., Rocha M., Barros L.V. 2004. Intraplate seismicity in SE Brazil: stress concentration in lithospheric thin spots. Geophysical Journal International, 159:390-399.

Barbiéro L., Queiróz-Neto J.P., Ciornei G., Sakamoto A.Y., Cappelari B., Fernandes E., Valles V. 2002. Geochemistry of water and groundwater in the Nhecolândia, Pantanal of Mato Grosso, Brazil: variability and associated process. Wetlands, 22:528-540.

Bezerra M.A.O. \& Mozeto A.A. 2008. Deposição de carbono orgânico na planície de inundação do Rio Paraguai durante o Holoceno médio. Oecologia Bras, 12:155-171.

Boggiani P.C. \& Coimbra A.M. 1995. Quaternary limestones of the Pantanal area, Brazil. Anais da Academia Brasileira de Ciências, 67:344-349.

Bridge J.S. 2003. Rivers and floodplains: forms, processes, and sedimentary record. Oxford, Wiley-Blackwell, 491p.

Brown Jr. L.F. \& Fisher W.L. 1977. Seismic-Stratigraphic Interpretation of Depositional Systems: Examples from Brazilian Rift and Pull-Apart Basins. In: Payton C.E. (ed.) Seismic stratigraphy - applications to hydrocarbon exploration: AAPG Memoir 26, p. 213-248

Buehler H.A., Weissmann, G. S.; Scuderi, L. A.; Hartley, A. J. 2011. Spatial and temporal evolution of an avulsion on the Taquari river distributive fluvial system from satellite image analysis. Journal of Sedimentary Research, 81:630-640

Cordeiro B.M., Facincani E.M., Filho A.C.P., Bacani V.M., Assine M.L. 2010. Compartimentação geomorfológica do leque fluvial do rio Negro, borda sudeste da Bacia do Pantanal (MS). Revista Brasileira de Geociências, 40:175-183.

Corradini F.A. \& Assine M.L. 2012. Compartimentação geomorfológica e processos deposicionais no megaleque fluvial do rio São Lourenço, Pantanal mato-grossense. Revista Brasileira de Geociências, 42:20-33.

Facincani E.M. \& Assine M.L. 2010. Geomorfologia fluvial do rio Aquidauana, borda sudeste do Pantanal Mato-Grossense. In: Martins Junior C. \& Oliveira Neto A.F. (ed.) Revelando Aquidauana. Campo Grande, Editora da UFMS, (Serie Fronteiras nº 3), 267-284.

Feng M., van der Lee S., Assumpção M. 2007. Upper mantle structure of South America from joint inversion of waveforms and fundamental mode group velocities of Rayleigh waves. J Geophys Res, 112 (B4):B04312.

Fraser L.H. \& Keddy P.A. 2005. The Word's Largest Wetlands - Ecology and Conservation. Cambridge University Press, 488 p.
Hamilton S.K., Sippel S.J., Melack J.M. 1996. Inundation patterns in the Pantanal wetland of South America determined from passive microwave remote sensing. Archiv für Hydrobiologie, 137:1-23.

Hartley A.J., Weissmann G.S., Nichols G.J., Warwick G.L. 2010. Large Distributive Fluvial Systems: Characteristics, Distribution, and Controls on Development. Journal of Sedimentary Research, 80:167-183.

Horton B.K., DeCelles P.G. 1997. The modern foreland basin system adjacent to the Central Andes. Geology, 25:895-898.

Junk W.J., Brown M., Campbell I.C., Finlayson M., Gopal B., Ramberg L., Warner B.G. 2006. The comparative biodiversity of seven globally important wetlands: a synthesis. Aquatic Sciences, 68:400-414

Kuerten S. \& Assine M.L. 2011. O rio Paraguai no megaleque do Nabileque, sudoeste do Pantanal Mato-Grossense, MS. Revista Brasileira de Geociências, 41: 642-653.

Kuerten S., Parolin M., Assine M.L., McGlue M.M. 2013. Sponge spicules indicate Holocene environmental changes on the Nabileque River floodplain, southern Pantanal, Brazil. Journal of Paleolimnology, 49:171-183.

Macedo H.A., Assine M.L., Pupim F.N., Merino E.R., Stevaux J.C., Silva A. 2014. Mudanças paleo-hidrológicas na planície do rio Paraguai, Quaternario do Pantanal. Revista Brasileira de Geomorfologia, 15:75-85

McGlue M.M., Silva A., Corradini F.A., Zani H., Trees M.A., Ellis G.S., Parolin M., Swarzenski P.W., Cohen A.S., Assine M.L. 2011. Limnogeology in Brazil's "forgotten wilderness": A synthesis from the large floodplain lakes of the Pantanal. Journal of Paleolimnology, 46:273-289.

McGlue M.M., Silva A., Zani H., Corradini F.A., Parolin M., Abel E.J., Cohen A.S., Assine M.L., Ellis G.S., Trees M.A., Kuerten S., Gradella F.S., Rasbold G.G. 2012. Lacustrine records of Holocene flood pulse dynamics in the Upper Paraguay River watershed (Pantanal wetlands, Brazil). Quaternary Research, 78:285-294

McGlue, M.; Silva, A.; Assine, M.; Stevaux, J.; Pupim, F. 2015. Paleolimnology in the Pantanal: Using Lake Sediments to Track Quaternary Environmental Change in the World's Largest Tropical Wetland. In: I. Bergier and M. L. Assine (eds.), Dynamics of the Pantanal Wetland in South America. Springer Berlin, Heidelberg.

Mendes D. 2014. Geocronologia de formas deposicionais e evolução da planície interleques do rio Negro, Quaternário da Bacia do Pantanal. Tese de Doutorado, Universidade Estadual Paulista UNESP, Rio Claro, SP, 97p.

Merino E.R., Assine M.L., Pupim F.D.N. 2013. Estilos fluviais e evidências de mudanças ambientais na planície do rio Miranda, Pantanal. Revista Brasileira de Geomorfologia, 14:127-134.

Miall A.D. 1996. The Geology of Fluvial Deposits. Berlin, SpringerVerlag, 582p.

Nanson G.C. \& Huang H.Q. 2008. Least action principle, equilibrium states, iterative adjustment and the stability of alluvial channels. Earth Surface Processes and Landforms, 33:923-942.

Nascimento A.F.; Furquim S.A., Graham R.C., Beirigo R.M., Junior J.C.O., Couto E.G., Vidal-Torrado P. 2015. Pedogenesis in a Pleistocene fluvial system of the Northern Pantanal - Brazil. Geoderma, 255:58-72

Nichols G.J. \& Fisher J.A. 2007. Processes, facies and architecture of fluvial distributary system deposits. Sedimentary Geology, 195:75-90.

Padovani C.R. 2010. Dinâmica das Inundações do Pantanal. Tese de Doutorado. Universidade de São Paulo - USP/ESALQ, Piracicaba - SP, 174p. 
Por F.D. 1995. The Pantanal of Mato Grosso (Brazil) - World's Largest Wetlands. Dordrecht, The Netherlands, Kluvwer Academic Publishers, 122p.

Pupim F.N., Assine M.L., Merino E.R., Macedo H.A., Silva A. 2014. A planície interleques do rio Piquiri, bacia do Pantanal. In: 50 Simposio de Geotecnologias no Pantanal, Campo Grande, MS, p.848-857.

Pupim F.N. 2014. Geomorfologia e paleo-hidrologia dos megaleques dos rios Cuiabá e São Lourenço, Quaternário da Bacia do Pantanal. MS Tese de Doutorado, Universidade Estadual Paulista - UNESP, Rio Claro - SP, 109p.

Shiraiwa S. 1994. Flexura da litosfera continental sob os Andes Centrais e a origem da Bacia do Pantanal. Tese de Doutoramento, Universidade de São Paulo, IAG, São Paulo.

Silva J.S.V. \& Abdon M.M. 1998. Delimitação do Pantanal brasileiro e suas sub-regiões. EMBRAPA, 33(Especial):1703-1711.

Sinha R. \& Friend P.F. 1994. River systems and their sediment flux, IndoGangetic plains, Northern Bihar, India. Sedimentology, 41:825-845.

Slingerland R. \& Smith N.D. 2004. River avulsions and their deposits. Annual Review of Earth and Planetary Sciences, 32:257-285.
Stouthamer E. \& Berendsen H.J.A. 2007. Avulsion: The relative roles of autogenic and allogenic processes. Sedimentary Geology, 198:309-325

Tooth S. 2000. Process, form and change in dryland rivers: a review of recent research. Earth-Science Reviews, 51:67-107.

Ussami N., Shiraiwa S., Dominguez J.M.L. 1999. Basement reactivation in a sub-Andean foreland flexural bulge: The Pantanal wetland, SW Brazil. Tectonics 18:25-39

Weissmann G.S., Hartley A.J., Nichols G.J.; Scuderi L.A., Olson M., Buehler H., Banteah R. 2010. Fluvial form in modern continental sedimentary basins: Distributive fluvial systems. Geology, 38:39-42.

Zani H., Assine M.L., McGlue M.M. 2012. Remote sensing analysis of depositional landforms in alluvial settings: Method development and application to the Taquari megafan, Pantanal (Brazil). Geomorphology, 161-162:82-92.

Arquivo digital disponível on-line no site www.sbgeo.org.br 